\title{
Martinho da Vila: uma nova linhagem do samba nos anos de $1970^{1}$
}

\author{
Adelcio Camilo Machado (UNICAMP, Campinas, SP) \\ adelcio.camilo@gmail.com
}

\begin{abstract}
Resumo: Após uma trajetória inicial como compositor ligado às escolas de samba, Martinho da Vila fez sua estreia na indústria fonográfica com o lançamento de seu primeiro LP Martinho da Vila, no ano de 1969. 0 presente texto trata da primeira faixa desse disco, que reúne três sambas de sua autoria: Boa noite, Carnaval de ilusões (em parceria com Gemeu) e Caramba. Através de apontamentos analíticos sobre seu arranjo, sua letra, sua melodia e sua harmonia, articulado a um panorama do contexto histórico em que foi produzido, busca-se desvendar alguns significados presentes nesse fonograma, percebendo-o como uma expressão de ideias e valores que se apresentavam para os artistas da música popular na passagem da década de 1960 para a de 1970.
\end{abstract}

Palavras-chave: música popular; samba; partido-alto; tradição.

\section{Martinho da Vila: a new lineage of Brazilian samba in the 1970s}

Abstract: After an initial career as a composer on samba schools, Martinho da Vila made his debut in music industry with the release of his first LP in 1969. This article discusses the first track of Martinho's album, which combines three sambas of his own: Boa noite [Good evening], Carnaval de ilusões [IIlusions carnival] (in partnership with Gemeu) and Caramba $[$ Wow]. Through analytical notes on their arrangement, their lyrics, its melody and its harmony along with the observation of the historical context in which it was produced, we seek to reveal some meanings of that phonogram, perceiving it as an expression of ideas and values presented for popular music artists in the transition of the 1960's to the 1970's.

Keywords: popular music; samba; partido-alto; tradition.

\section{1 - "Tradição" e "modernização" no samba}

0 reconhecimento do samba como um gênero musical data das primeiras décadas do século XX. Inicialmente identificado como prática circunscrita a redutos onde se concentrava a população de ex-escravos no Rio de Janeiro e associado ao mundo da malandragem, ele foi promovido, especialmente durante o período getulista, à condição de símbolo da brasilidade. A expansão do mercado de música popular, impulsionada pelo desenvolvimento da indústria fonográfica e pela consolidação da radiofonia comercial, se constituiu na base a partir da qual atuaram inúmeros agentes individuais e coletivos na conversão do samba no segmento musical representativo da nacionalidade. Como observa VIANNA (1995), não foram apenas os afro-descendentes que protagonizaram esse processo, mas outros segmentos sociais como ciganos, baianos, cariocas, intelectuais, políticos, folcloristas, compositores eruditos, milionários etc., cada um ao seu modo e movidos por objetivos diversos, promoveram a um só tempo sua fixação e nacionalização. Mas a promoção do samba à condição de símbolo da identidade cultural brasileira se deu em meio a um campo de forças balizado por construções ideológicas diversas que podem ser agrupadas em duas grandes perspectivas: a da valorização da "tradição" e a da sua "modernização". Em determinados momentos, tais perspectivas oscilaram entre movimentos de confluência e oposição.

Ainda nos anos de 1930, a construção da ideia de "tradição" do samba implicou na identificação dos morros cariocas, espaços ocupados por segmentos sociais populares, como berço ${ }^{2}$ desse repertório, uma espécie de lugar mítico de onde emanavam os mais "autênticos" elementos da nossa cultura popular. Conforme explicitado por Natpolitano, nesse momento verificava-se o movimento de subida ao morro como maneira de entrar em contato direto com essa "tradição":

\footnotetext{
A partir de 1935, incrementou-se a prática das visitas organizadas aos morros e às escolas de samba, por parte de personalidades nacionais e estrangeiras, ciceroneadas pelos mediadores de plantão: artistas cultos, intelectuais boêmios e sambistas das
} 
comunidades envolvidas. Esse movimento simbólico buscava reafirmar a nacionalidade ancorada nas tradições populares, para reinventar as bases da brasilidade e redirecionar os caminhos da arte brasileira, culta e popular (NAPOLITANO, 2007, p.33)

Ao mesmo tempo em que a "autenticidade" aparecia como um sinal de legitimidade do samba, ganhava força o movimento orientado por uma perspectiva mais conservadora que postulava a necessidade de "higienizá-lo" e "discipliná-lo" (NAPOLITANO, 2007, p.44). Tal empreitada mobilizava ações diversas como a "melhoria da qualidade poética" das letras, o abandono das temáticas ligadas à malandragem como a apologia à vadiagem e o refinamento musical das composições. Ary Barroso parece ter traduzido plenamente essas metas em Aquarela do Brasil, música que se converteu no exemplo emblemático da safra de composições identificada como "samba-exaltação". Para Marcos Napolitano, esse cancionista se mostrava partidário

\begin{abstract}
da fusão dos temas urbanos do samba com as letras de motes folclóricos e passadistas, ao mesmo tempo em que apoiava a modernização musical do samba, por meio de novas harmonias mais sincronizados com a música popular internacional, cujo paradigma era a música norte-americana. Portanto, o samba deveria "abrir a cortina do passado" nacional e realizar a fusão com a tradição, sem negligenciar a modernidade (NAPOLITANO, 2007, p.44-5).
\end{abstract}

Se Aquarela do Brasil representou, nos anos de 1940, uma maneira de conciliar "tradição" e "modernização", na década seguinte, a polarização entre essas duas perspectivas se acentuou. 0 debate entre os que valorizavam a adoção de procedimentos jazzísticos como estratégia de refinamento da música popular e os adeptos da preservação da "pureza" das nossas tradições culturais aparece nas páginas da Revista da Música Brasileira, editada por Lúcio Rangel, que circulou durante os anos de 1954 e 1955. Conforme nos mostra a pesquisadora Joana SARAIVA (2007), essa revista foi porta-voz de um amplo debate sobre o jazz, que era visto por alguns como fonte de procedimentos que descaracterizavam a música brasileira, mas por outros, como um símbolo de "modernização".

Em 1955, dois lançamentos fonográficos traduziram esse confronto. 0 primeiro foi a composição Rapaz de bem de Johnny ALF (1955, 78 rpm), lançada pela gravadora Copacabana. Trata-se de um samba que contém elementos característicos do jazz norte-americano, que aparecem em determinados aspectos da composição como a progressão harmônica e a organização da seção rítmica. A letra faz referência à boa vida dos jovens da zona sul do Rio de Janeiro, região da cidade habitada pela classe média carioca. Essa música, sintonizada com a perspectiva da "modernização" do samba, foi considerada como uma das precursoras da bossa nova ${ }^{3}$. A segunda foi a composição de Zé Kéti, intitulada $A$ voz do morro, interpretada por Jorge Goulart e lançada pela Continental (GOULART, 1955, 78 rpm). Trata-se de um samba "tradicional" cuja letra enfatiza os espaços míticos da "tradição" como o morro, o terreiro e a cidade do Rio de Janeiro: "Eu sou o samba / A voz do morro sou eu mesmo, sim senhor / Quero mostrar ao mundo que tenho valor / Eu sou o rei do terreiro / Eu sou o samba / Sou natural daqui do Rio de Janeiro".

Ao longo da década de 1960 o embate entre a "tradição" e a "modernização" ganhou novos contornos. Orientados pelo ideário nacional-popular redefinido por organizações e intelectuais de esquerda, juntamente com o Centro Popular de Cultura (CPC da UNE), artistas da música popular buscaram conhecer melhor a música do "povo" com o objetivo de se integrar a ele, promovendo a sua autoconsciência enquanto sujeito revolucionário. Nesse sentido, houve tanto uma nova ênfase nos morros e nas escolas de samba como detentores da "autenticidade" do samba quanto uma ampla politização da canção popular. Assim, a "tradição" aparecia intimamente vinculada ao engajamento político. Sambas como Zelão de Sérgio Ricardo, interpretado pelo autor em gravação de 1960 (RICARD0, 1960, LP), e Influência do jazz, de Carlos Lyra, lançado pela Philips em 1963 (LYRA, 1963, LP), são bons exemplos dessa nova tendência. 0 primeiro empregava um estilo vocal semelhante ao de Dorival Caymmi, mas com arranjo bossanovista, e se referia ao sofrimento da população pobre dos morros cariocas: "Todo morro entendeu quando Zelão chorou / ninguém riu, ninguém brincou e era carnaval". 0 segundo é um samba-jazz cuja letra aborda o problema da descaracterização do samba em decorrência da incorporação de traços estilísticos do jazz. Para se livrar das influências estrangeiras e renascer em toda sua "autenticidade", o compositor propõe ao "pobre samba": "Volta lá pro morro / E pede socorro / Onde nasceu".

No entanto, essas composições mostram que alguns dos artistas mais comprometidos com o projeto da canção engajada e nacionalista, ao mesmo tempo em que buscavam assimilar modos de expressão característicos da cultura popular, não deixavam de lado elementos musicais considerados inovadores. Eles buscavam conciliar o vínculo com a "tradição" e com "modernidade" estética. "Sou a favor das influências estrangeiras, desde que não destruam as raízes culturais nacionais", dizia Carlos Lyra, fundador e diretor do Departamento de Música do CPC (ABRIL CULTURAL, 1971). Essa tendência se consolidou principalmente após o golpe militar de 1964, quando a música popular politizada passou a ocupar maiores espaços nos meios de comunicação de massa, especialmente na televisão. Exemplos disso foram o programa O Fino da Bossa da TV Record e os Festivais de Música Popular Brasileira e da Canção, promovidos pelas emissoras TV Excelsior, TV Record e TV Globo. Nesse período, no qual se verifica a configuração de um novo contexto de produção, divulgação e consumo de bens culturais apoiado no desenvolvimento da indústria cultural, emerge um amplo segmento fonográfico identificado pela sigla MMPB (Moderna Música Popular Brasileira), posteriormente simplificada para MPB. Buscando articular "tradição" e "modernização", essa sigla expressava o que Ridenti nomeou de "romantismo revolucionário", ou seja, uma construção ideológica que buscava "no passado (as raízes populares nacionais) as 
bases para construir o futuro de uma revolução nacional modernizante que, no limite, poderia romper as fronteiras do capitalismo" (RIDENTI, 2000, p.51). Esse segmento se consolidou na segunda metade da década de 1960, abrigando um leque de tendências da canção nacionalista como o samba "autêntico", as composições concebidas a partir da estilização de material "folclórico" ou de "gêneros convencionais de raiz", e as canções parodisticas da Tropicália (NAPOLITANO, 2007, p.110).

Durante os anos 1970, a tensão entre o "tradicional" e o "moderno" parece ganhar novos sentidos. A reconfiguração desses parâmetros se deu num contexto complexo que se delineou principalmente a partir de final do decênio anterior. A repressão política, acompanhada pelo recrudescimento da prática da censura, que se impôs à sociedade após a decretação do Al-5 em dezembro de 1968, o desenvolvimento indústria cultural, impulsionando a consolidação do mercado de bens simbólicos no país, e o crescimento econômico acelerado, resultante da política de modernização conservadora, produziram fortes impactos sobre a arte e a cultura. 0 General Médici, que personificou o período mais sombrio do regime ditatorial militar, tentou fomentar um clima de euforia, especialmente entre setores de classe média que se beneficiaram da expansão econômica, denominado "milagre brasileiro", com discursos pautados por um nacionalismo ufanista. A conquista do tri-campeonato de futebol pela seleção brasileira em 1970, por exemplo, foi claramente instrumentalizada pelo governo. Ao mesmo tempo, a indústria cultural incorporou aspectos da brasilidade nacional-popular que se traduziram especialmente nos conteúdos de programas televisivos nos anos 70. De certo modo, esse ideário aos poucos foi perdendo o sentido utópico e se integrando à ordem autoritária. Como afirma Ridenti,

após as derrotas de 1964 e 1968, a busca romântica da identidade nacional do homem brasileiro permaneceria, porém mudavam as caracteristicas desse romantismo, que foi deixando de ser revolucionário para encontrar um lugar na nova ordem (RIDENTI, 2010, p.106)

No âmbito da música popular, se a censura muitas vezes cerceou a produção de muitos compositores, em outros momentos exigiu desses artistas habilidades para adotar, como diz Tatit, "manobras criativas" visando enganar os censores e fazer com que seus recados chegassem até os ouvintes. Ao mesmo tempo, os processos criativos deixaram de ser norteados por parâmetros subjetivos, como acontecia nos anos anteriores, e se tornaram cada vez mais pautados pelas "leis frias do mercado" (TATIT, 2004, p.228). Nesse cenário, os marcos que orientavam a tomada de posição no campo da produção musical começaram a se confundir. A intervenção tropicalista produziu abalos profundos nas polarizações tradicional/ moderno, nacional/internacional, bom gosto/mau gosto, as quais se manifestavam, por exemplo, nos confrontos entre música engajada e música alienada, MPB e Jovem Guarda (TATIT, 2004, p.209). Mais do que isso, a vanguarda tropicalista pôs em xeque os critérios político-ideológicos de exclusão de parte significativa da produção musical da época, possibilitando que a canção brasileira passasse a incorporar novas dicções. De certo modo, o rompimento dessas comportas representou um primeiro sinal do enfraquecimento da legitimidade da ideia de identidade nacional. Aos poucos, verificou-se em determinadas frentes a desarticulação entre popular e nacional. A configuração brasileira da contracultura, as atenções voltadas para questões ligadas à sexualidade, às drogas, à marginalidade do artista, à negritude, juntamente à tendência da idilização do passado comunitário, resultaram na valorização de um popular que, ao invés de se identificar com a nação, expressava a busca por outras identidades de recortes regionais ou locais. Tais representações se refletiram de alguma forma em vários campos artísticos dos anos 70, em especial na música popular. Foi nesse ambiente que Martinho da Vila iniciou sua carreira como compositor e intérprete profissional.

\section{2 - Martinho da Vila, partido-alto e a MPB}

Martinho José Ferreira nasceu no ano de 1938 em uma fazenda na cidade de Duas Barras - RJ. Ainda menino, sua família se mudou para o Rio de Janeiro, passando a residir na Serra dos Pretos Forros, morro situado no Bairro de Lins de Vasconcelos. Após a morte do pai, a família, muito pobre, se dispersou e Martinho foi viver na casa de duas professoras solteironas onde se dedicou a atividades domésticas e teve a oportunidade de estudar. Ele mesmo dizia que tivera dois tipos de formação: no morro, convivendo com crianças da sua classe, jogando "peladas" e vivenciando práticas e rituais da religiosidade afro-brasileira, e na casa da cidade, onde além de estudar, recebeu formação católica. Preocupado com a sobrevivência, ao concluir o curso primário, procurou pelo SENAI onde acabou se especializando em química industrial e farmácia. Após ingressar no serviço militar, seguiu carreira e chegou ao posto de sargento.

Martinho se inseriu no meio musical através das escolas de samba. Na época em que morou na Serra dos Pretos Forros, participou da Acadêmicos da Boca do Mato, primeiramente tocando frigideira e tarol, depois como compositor (CABRAL, 1996, p.358). Mais tarde, transferiuse para a Unidos de Vila Isabel, onde se tornou Martinho da Vila. Em 1967, compôs o enredo Carnaval de ilusões, obtendo boa repercussão no desfile. Isso Ihe motivou a inscrever a canção Menina moça no III Festival de Música Popular Brasileira da TV Record, composição que ficou entre as 30 selecionadas para as etapas finais do certame. No ano seguinte, concorreu no IV Festival da mesma emissora com Casa de bamba, composição que Ihe abriu espaços no mundo do disco. Essa canção foi incluída no LP Philips IV Festival da Música Popular Brasileira - TV Record (Vol.1), de 1968, e no ano seguinte foi gravada por Jair Rodrigues no LP Jair de Todos os Sambas (Vol. 1), lançado pela mesma gravadora, onde ainda consta outra canção de sua autoria, intitulada Pra que dinheiro. 
Em 1969, Martinho foi convidado pela RCA Victor para gravar seu primeiro LP contendo 12 canções de sua autoria. A partir desse ano sua carreira deslanchou e Martinho da Vila se projetou como um cancionista de grande popularidade, lançando um LP por ano, todos pela RCA Victor, acompanhados por compactos simples e duplos, os quais apresentaram um considerável sucesso no mercado musical. Apenas para se ter uma amostra, de acordo com dados sobre vendagem de discos publicados mensalmente pelo IBOPE do Rio de Janeiro, durante os anos de 1974 e 1976, o nome de Martinho apareceu entre os mais vendidos em todos os meses, alcançando ainda, nesse mesmo período, a primeira colocação por quatorze vezes ${ }^{4}$.

Olhando para o conjunto da discografia de Martinho nota-se a presença de elementos visuais, performáticos, discursivos e musicais que revelam a preocupação de se criar uma aura de "tradição" e "autenticidade" sobre essa produção. Operando com aspectos da própria biografia do compositor, agentes da indústria e críticos construíram a imagem de um sambista genuíno, que fala a partir de dentro da cultura popular. Vale destacar que Martinho não foi passivo nessa empreitada; de certo modo, soube se posicionar como protagonista de todo o processo.

Uma característica marcante do estilo de Martinho, enfatizada por ele e por alguns de seus críticos, é o emprego de aspectos do partido-alto. De acordo com o compositor e antropólogo Nei LOPES (1992), o termo partido-alto comporta uma série de significados, tanto entre os "partideiros" quanto entre os estudiosos. 0 autor informa que, para Zinho, sobrinho da Tia Ciata ${ }^{5}$, o "verdadeiro" partido-alto não era cantado, mas instrumental. Já para João da Baiana, o partido-alto era cantado em dupla, trio ou quarteto, com os solistas improvisando versos para que os demais presentes sambassem, e exemplifica com a canção Patrão, prenda seu gado (LOPES, 1992, p.47-48). Escutando-se esse partido-alto na gravação de ALMIRANTE (1968, LP), notase uma considerável simplicidade harmônica, uma vez que na estrofe são ouvidos somente os acordes de Tônica e Dominante e no refrão estes são acrescidos pelo acorde de Subdominante. Percebe-se também o uso de versos curtos e, sempre que possível, rimados: "Ô, patrão, prenda seu gado / Na lavra tem um ditado / Quem mata gado é jurado / Missa de padre é latim / Rapaz solteiro é letrado / Em vim preso da Bahia / Porque era namorado".
Alguns dos primeiros registros fonográficos rotulados como samba apresentam características que permitem associá-los ao partido-alto. Esse é o caso do famoso Pelo telefone, de 1917, considerado durante muito tempo como o primeiro samba gravado ${ }^{6}$, mas que se trata, de fato, de uma criação coletiva, improvisada, dos frequentadores da casa da Tia Ciata, que foi fixada por Donga e Mauro de Almeida, sendo posteriormente registrada em disco pelo cantor Baiano. Nessa composição se observa uma simplicidade harmônica e melódica, juntamente com versos curtos, especialmente em trechos como "Ai, se a rolinha / Sinhô, sinhô / Se embaraçou / Sinhô, sinhô / É que a avezinha / Sinhô, sinhô / Nunca sambou / Sinhô, sinhô".

Segundo o professor, baterista e percussionista Oscar BOLÃO (2010), o partido-alto apresenta ainda um padrão rítmico característico, geralmente executado pelo pandeiro, que o diferencia do samba urbano. Enquanto o acompanhamento do pandeiro no samba se caracteriza apenas pela subdivisão da pulsação, no partido-alto esse instrumento costuma executar uma figuração rítmica peculiar, como se vê no Ex.1:

Em boa parte dos fonogramas de Martinho, ouve-se uma levada rítmica bastante próxima a esta apresentada por Bolão e considerada típica do partido-alto. Por sua vez, o próprio Martinho entende que é esse tipo de acompanhamento que caracteriza a "cadência" do partido-alto ${ }^{7}$. Sobre essa base rítmica, versos curtos $^{8}$ são entoados a partir de melodias e harmonias simples, geralmente contendo sequências de três ou quatro acordes que se repetem ao longo de toda a canção ${ }^{9}$ e com melodias consistindo basicamente em arpejos desses mesmos acordes, lembrando cantigas folclóricas. 0 canto falado de Martinho, com ênfase nos cortes nas consoantes, reforça a pulsação rítmica, bem como o caráter despojado e bem humorado do partido-alto ${ }^{10}$.

Ao longo da trajetória de Martinho nota-se ainda a preocupação do compositor e dos produtores em (re)criar o clima de simplicidade e a espontaneidade das rodas de samba. Ao descrever o processo de gravação de seu primeiro $L P$, por exemplo, Martinho destaca seu caráter espontâneo, veiculando a ideia de que eles teriam feito uma roda de samba dentro do estúdio e que todas as intervenções teriam acontecido posteriormente.
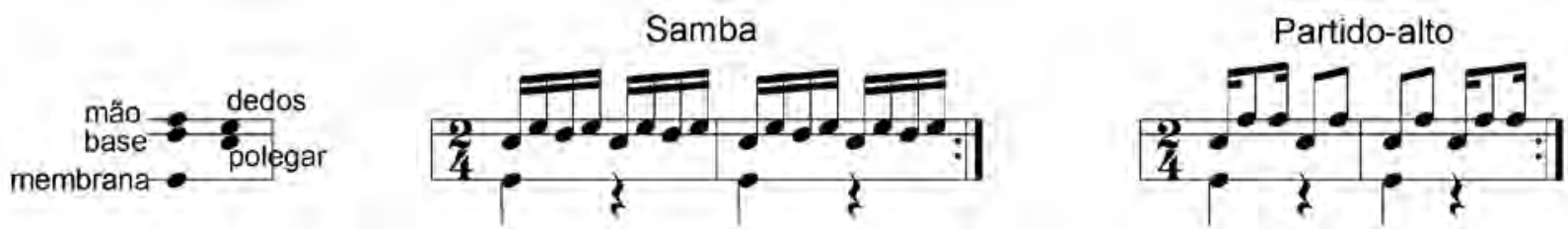

Ex.1 - Padrões rítmicos do pandeiro no samba e no partido-alto segundo BOLÃO, 2010, p.24 e 93. 
Aí fui para o estúdio, levei um cara do cavaquinho, outro com pandeiro, eu mesmo toquei o tantã e fui gravando. Eu e o técnico só lá, nunca tinha entrado em um estúdio. Aí, logo depois me chamaram lá. Quando eu cheguei, estava todo mundo numa euforia danada [...]. "Olha, nós já temos o disco!" [...] Eu falei: "Mas vocês já escolheram as músicas?" "Já escolhemos! Olha, aquele monte de música que tem lá dá pra fazer dois discos! Já vamos fazer um disco com aquelas tuas músicas lá. Aquele é o disco, já temos, vamos só melhorar um pouquinho umas coisas, fazer uma mixagem, botar mais um trombonezinho, botar um coro, um vocal..." (VILA, 2008, DVD, 16min49s a 17min57s).

De fato, ao se escutar o primeiro disco de Martinho, não se percebe nele a existência de grandes introduções instrumentais ou de arranjos complexos. Ao contrário, existe uma considerável simplicidade no que se refere à parte musical. Das doze faixas que compõem o LP, em duas delas (Quem é do mar não enjoa e Pra que dinheiro) não há introduções instrumentais, mas é o próprio Martinho que entra cantando sozinho, sem acompanhamento; somente após a entrada do vocal é que os instrumentos da seção rítmica tocam. Em outros quatro fonogramas (Quatro séculos de modas e costumes, Casa de bamba, Brasil mulato e Parei na sua / Nhêm, nhêm, nhêm), somente o acorde de tônica é tocado pelos instrumentos harmônicos, juntamente com a percussão, fornecendo ao cantor a tonalidade e o andamento da canção. Os três fonogramas com introduções mais extensas e com maior grau de elaboração (O pequeno burguês, Tom maior e Grande amor) não vão além da execução de trechos das melodias pelo trombone com o acompanhamento da seção rítmica.

Por sua vez, no segundo LP do sambista, Meu laiaraiá (VILA, 1970, LP), percebe-se um cuidado maior na elaboração dos arranjos, com a criação de introduções mais extensas e a incorporação de outros instrumentos como cordas, madeiras, contrabaixo, bateria e piano. Contudo, ao mesmo tempo, verifica-se uma preocupação em não deturpar a "pureza" de Martinho da Vila. Isso se encontra expresso de modo bastante claro em um pequeno texto na contracapa do LP, escrito pelo produtor Romeo Nunes:

Tivemos o cuidado de cercar a voz selvagem de MARTINHO de arranjos leves, simples e funcionais (de Severino Filho e Ivan Paulo) mantendo intacta a base de autenticidade de suas composições (NUNES, 1970).

Ao longo da discografia produzida por Martinho durante os anos 1970 podem ser encontrados novos exemplos dessa preocupação com a "autenticidade". Isso se manifesta, por exemplo, na gravação de faixas que reúnem vários sambas numa espécie de pout pourri, conectados por intermédio de comentários falados do próprio intérprete, simulando o ambiente de uma roda de samba. Tal procedimento foi empregado já na primeira faixa de seu LP de estreia (VILA, 1969, lado A, faixa 1) e depois em Seleção de partido-alto (VILA, 1971, lado B, faixa 1), em Sambas de roda e partido alto (VILA, 1972, lado B, faixa 1) em Tributo a Monsueto (VILA, 1973, lado A, faixa 1) e em duas faixas de seu LP Tendinha (VILA, 1978, lado A, faixa 2 ( lado B, faixa 2).
Outra forma de estreitar seu vínculo com a "tradição" se deu através das regravações que Martinho fez de composições dos "pioneiros" do samba. Em seu LP de 1972, ele gravou o partido-alto Batuque na cozinha, de João da Baiana (VILA, 1972, lado B, faixa 1), canção que ainda deu o título ao disco. No ano seguinte, o sambista registrou Pelo telefone, de Donga e Mauro de Almeida (VILA, 1973, lado B, faixa 1) e, por fim, em 1974, lançou sua versão do partido-alto Patrão, prenda seu gado, composto por Donga, Pixinguinha e João da Baiana (VILA, 1974, lado B, faixa 1). Ao regravar esses sambistas, já plenamente legitimados àquela época, Martinho da Vila acabava firmando em bases mais sólidas a sua proximidade com a "tradição" do samba, como expressou o crítico musical Tárik de Souza: "Martinho construiu uma obra de sólidos alicerces edificados sobre as formas dos pioneiros (Donga, João da Bahiana, Monsueto) a quem gravou meticulosamente" (SOUZA, 1983, p.168).

A despeito de todo esse vínculo que Martinho buscava estabelecer com a "tradição", cabe lembrar que até então o samba se encontrava circunscrito aos limites da MPB, o que significa dizer que os mesmos ideais de "modernização" que norteavam a produção deste segmento também deveriam balizar a produção dos sambistas. Isso fez com que parte do repertório de Martinho da Vila enfrentasse resistência de alguns de seus pares, uma vez que o cancionista retomava um tipo de samba mais primitivo, que não tinha vínculos com o processo de "modernização" e refinamento que essa produção havia experimentado ao longo dos anos. Nesse sentido, as declarações de Pixinguinha sobre Martinho são emblemáticas, pois, para o maestro, o samba de Martinho era "a coisa mais mediocre que existe" (citado em SOUZA e ANDREATO, 1979, p.235). Isso porque, por mais que Pixinguinha também tivesse apresentado vínculos com o partido-alto mais "tradicional", o compositor foi formando seu habitus em meio ao processo de "modernização" do samba. Isso se percebe ainda pelo fato de que no mesmo festival em que Jamelão defendeu o primitivo partido-alto Menina moça de Martinho, Elza Soares apresentava o moderno samba Isso não se $\mathrm{faz}_{\mathrm{I}}$ composto por Pixinguinha e Hermínio Bello de Carvalho, com progressões harmônicas mais ousadas e melodias menos diatônicas.

Nota-se, assim, que a música de Martinho era produzida em meio a uma tensão entre, de um lado, a busca pela "tradição" e "autenticidade" e, de outro, o refinamento do samba no contexto da MPB. A seguir, procuraremos apontar de que modo esses ideais já apareceram no primeiro fonograma de seu LP de estreia, ou seja, na faixa que simbolicamente 0 introduziu no mercado de discos. Nela se encontram reunidos três sambas de Martinho, Boa noite, Carnaval de ilusões e Caramba, todos precedidos por um comentário do próprio autor. A descrição e a análise desses sambas revelam tanto as ações estratégicas implementadas por Martinho para se integrar ao mercado musical como os novos sentidos que o samba irá adquirir ao longo da década de 1970. 


\section{3 - Boa noite: o pregão de um sambista "autêntico"}

A primeira canção desse fonograma, Boa noite, consiste em um samba de quadra composto por Martinho para saudar os integrantes da Escola de Samba Unidos de Vila Isabel. Contudo, antes de interpretá-lo, Martinho inicia um diálogo com seu ouvinte, num tom coloquial e com uma entonação alegre, bem-humorada:

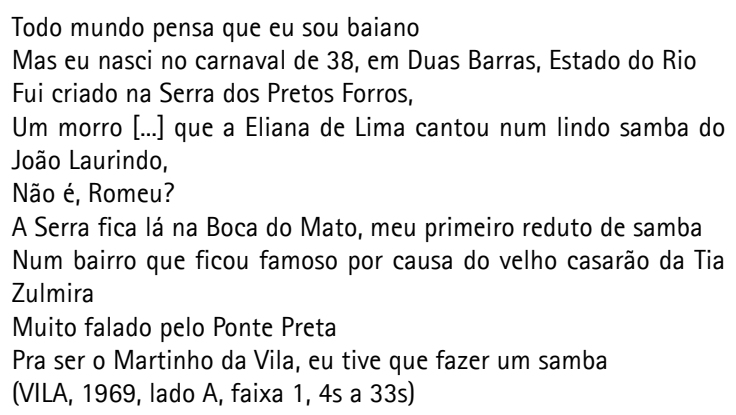

Um início como esse confere certo caráter de espontaneidade ao fonograma. De certo modo, ele simula o ambiente informal de uma roda de samba no qual Martinho se apresenta ao público, numa espécie de pregão no qual o sambista fala das suas origens e da sua trajetória. 0 conteúdo do texto revela a tentativa de atribuir a marca de sambista "autêntico", não se limitando a contar que nascera no ano de 1938, mas sim no carnaval de 1938. $E_{1}$ ao que parece, essa não é uma menção gratuita: ao destacar o fato de que havia nascido no carnaval, é como se Martinho insinuasse que nascera predestinado a ser sambista. Tal relação se encontra implicitamente desenvolvida em sua composição Linha do Ão, gravada no LP Meu laiaraiá, de 1970, quando Martinho sugere que sua ligação com a música popular teria um caráter hereditário, uma vez que seu pai era um bom improvisador ao som do calango: "O meu pai era colono / E meeiro muito bom / Calangueava a noite inteira / Não perdia verso, não" (VILA, 1970, lado B, faixa 4). Cabe lembrar que, segundo LOPES (1992, p.29-30), o calango foi objeto de interesse por parte de pesquisadores do folclore brasileiro. Trata-se de uma manifestação afro-brasileira inicialmente ligada ao universo rural, sobretudo ao estado de Minas Gerais, e depois também a São Paulo, ao Rio de Janeiro e ao Espírito Santo, que, dentre outros elementos, caracteriza-se pelo desafio ${ }^{11}$, em geral entre dois cantores, de se criar versos improvisados no momento da performance. Portanto, essa alusão ao pai de Martinho como hábil na improvisação de versos servia para indicar uma espécie de virtude hereditária que o sambista supostamente teria.

0 texto desse comentário também faz referência à primeira escola de samba frequentada por Martinho, a Acadêmicos da Boca do Mato, e contextualiza o samba Boa noite (Ex.2), que é apresentado em sequência: tratase de uma composição que marca a saída do sambista da Boca do Mato e seu ingresso na Vila Isabel. Como uma espécie de cartão de visita para a sua nova escola, o sambista compôs uma canção em que saudava os integrantes da Vila Isabel - diretor de bateria, sambistas, compositores, presidentes, diretores, diretor de harmonia e pastoras - e mostrava seu entusiasmo para trabalhar pela escola ("Pra Vila eu trago / Toda a minha inspiração").

Atentando-se para a construção harmônica e melódica desse samba, pode-se constatar a mesma simplicidade comentada anteriormente. Harmonicamente, percebese 0 uso de apenas quatro acordes diatônicos, os quais, por sinal, são os únicos acordes ouvidos durante os quase seis minutos do fonograma em questão. Do ponto de vista melódico, destaca-se a pouca ocorrência de graus conjuntos, em virtude da melodia apresentar muitas notas de acordes. As frases "Boa noite, Vila Isabel" e "Quero brincar o carnaval" (c.17), por exemplo, apresentam somente as notas do acorde de $\mathrm{Bb}$; do mesmo modo, a frase "Boa noite, diretor de bateria" também contém exclusivamente notas do acorde de $\mathrm{Cm}$. Com isso, tem-se uma melodia majoritariamente construída com consonâncias. Tal aspecto pode ser compreendido pelo fato de que não há nenhuma menção de que Martinho domine um instrumento harmônico; isso significa que, para que os instrumentistas que o acompanhavam conseguissem deduzir a harmonia, era preciso que esta já estivesse desenhada na própria melodia. Contudo, conforme já exposto, isso entrava em conflito com os ideais da $M P B$, segmento hegemônico que também se pautava pela busca de refinamento estético ${ }^{12}$.

Além de enfatizar sua ligação com a escola de samba, polo de "autenticidade", Martinho também lembra, já no segundo verso de Boa noite, que a Vila Isabel é a terra de Noel Rosa, personagem reconhecido não só como um dos mais importantes compositores da nossa música popular, mas como representante legítimo da "tradição" do samba $^{13}$. Curioso seria perceber, porém, que Noel Rosa se relaciona justamente a um tipo de samba diverso daquele que estava sendo produzido por Martinho: enquanto este se apropriava de um samba mais primitivo, no caso, o partido-alto, Noel é um dos personagens centrais na "modernização" do samba, sobretudo no sentido de seu refinamento poético, de seu afastamento do universo afroreligioso e de sua nacionalização.Enquanto que em Feitiço da Vila, de Noel Rosa, ouve-se que "A Vila tem / Um feitiço sem farofa / sem vela e sem vintém / Que nos faz bem", num movimento de afastar o samba dos rituais religiosos da comunidade negra em sua época, o partido-alto Casa de bamba de Martinho da Vila canta: "Macumba lá na minha casa / tem galinha preta, azeite de dendê". Divergências à parte, ao ingressar na Vila Isabel, Martinho não perde a oportunidade de se apoiar nos ombros desse "gigante" do samba.

\section{4 - Carnaval de ilusões: renovação do samba- enredo através do partido-alto}

Após cantar Boa noite, Martinho da Vila aparece novamente conversando com seus ouvintes. Em um comentário muito rápido, o sambista anuncia o próximo samba a ser interpretado: "Em 67, a Vila chegou na (sic) 

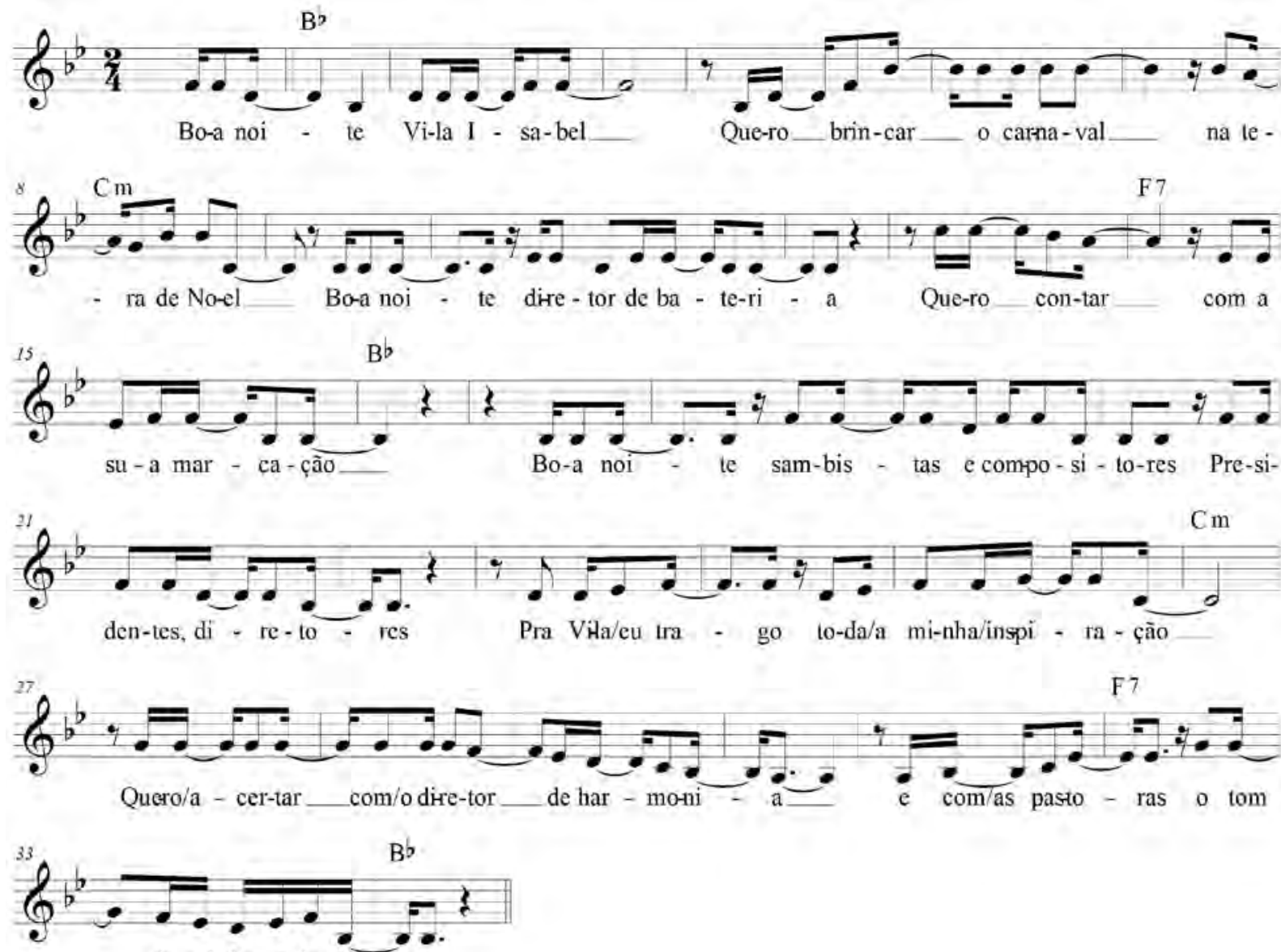

da mi-nha me-lo-di_a

Ex.2 - Boa noite (VILA, 1969, lado A, faixa 1, 34s a 1min9s)

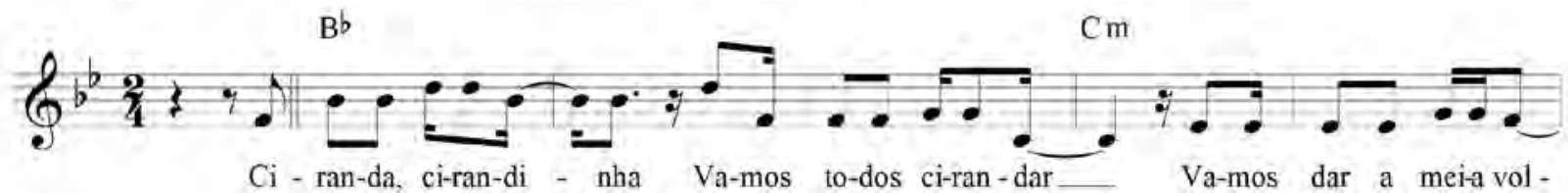

F7

$\mathrm{Bb}$

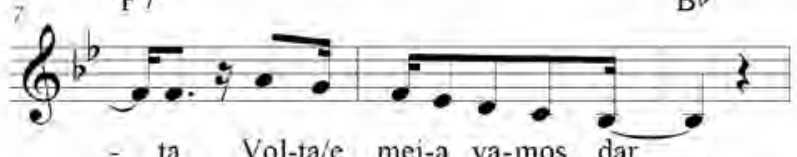

Ex.3 - início de Carnaval de ilusões (VILA, 1969, lado A, faixa 1, 1min35s a 1min43s)

cidade com um enredo genial! Gabriel e Dario bolaram um carnaval de ilusões, sonhado por uma criança" (VILA, 1969, lado A, faixa 1, 1min24s a 1min34s). Imediatamente começa a cantar o refrão de Carnaval de ilusões, samba-enredo composto para o desfile da Vila Isabel em 1967. Sua letra, escrita por Gemeu, fazia referências ao universo infantil, criando um clima de sonho e de imaginação. A canção (Ex.3) se inicia citando a cantiga de roda Ciranda, cirandinha:

Enquanto o coro feminino repete esse refrão, Martinho declama o texto original de Gemeu, onde se percebem várias figuras do mundo infantil - os folguedos infantis, a bola, a bonequinha e o carrossel - embalados por um clima de sonho e imaginação ("Fantasia, deusa dos sonhos esteja presente", "seres do teu reino encantado").

Fantasia, deusa dos sonhos esteja presente Nos devaneios de um inocente

Ó soberana das fascinações

Põe os seres do teu reino encantado

Desfilando para o povo deslumbrado

Num carnaval de ilusões

$\mathrm{Na}$ doce pausa dos folguedos infantis

Repousam a bola e a bonequinha querida

No turbilhão do carrossel da alegre vida 
Morfeu embala a criança tão feliz

Como num sonho encantador

Viaja ao mundo da fabulação

(VILA, 1969, lado A, faixa 1, 1min46s a 2min21s)

Depois disso, Martinho volta a cantar (Ex.4):

Enfim, à semelhança do que havia acontecido anteriormente, o coro feminino repete esse trecho da canção, enquanto Martinho declama outra parte do texto original de Gemeu, trazendo novos elementos ligados à infância (fada, figuras lendárias, personagens de leituras):

\author{
Guiadas pela fada Ilusão \\ Se juntam lendárias figuras \\ Personagens de leituras \\ Revividos na memória \\ Que ajusta ao imperfeito \\ A perfeição dos conceitos \\ De deleitosas histórias \\ (VILA, 1969, lado A, faixa 1, 2min38s a $2 \min 55 s$ )
}

0 fato de Martinho declamar trechos dessa canção ao invés de cantá-la por inteiro sugere que ele pretende destacar o texto de Gemeu. Isso se deve ao fato de que a temática desenvolvida por Gemeu e transformada por Martinho em samba-enredo era algo diferenciado em relação ao que usualmente acontecia nesse segmento do samba. Isso porque até então os sambas-enredo costumavam abordar "grandes" personagens ou "grandes" eventos da história brasileira, repertório que ficou conhecido como "samba-lençol"14. Para se ter um exemplo disso, no mesmo ano em que a Vila desfilou com Carnaval de ilusões, a Mangueira sagrou-se a campeã do carnaval com o samba-enredo 0 mundo encantado de Monteiro Lobato. Essa referência ao "mundo encantado", presente no título desse samba-enredo, sugere que a canção vá homenagear o escritor em questão por sua produção infanto-juvenil. Contudo, ao longo de seu texto, são muito breves as alusões a esse universo da fantasia, que ficam restritas ao trecho "Relembro / Aquele mundo encantado / Fantasiado de dourado / Oh, doce ilusão / Sublime relicário de criança". De resto, a composição consiste em uma série de elogios ao "escritor genial", "grande sonhador", possuidor de "uma luz divinal", de uma "escritura emocionante" e criador de "obras imortais", "contos triunfais" e "personagens fascinantes". Mesmo abordando algo que se liga ao universo infantil, a canção não priorizou a descrição desse universo, tal qual acontece no samba-enredo de Martinho, mas se preocupou em exaltar (monumentalizar) a figura de Monteiro Lobato. Do ponto de vista harmônico, não se observa um diatonismo estrito, mas aparecem algumas Dominantes individuais e o acorde de Subdominante menor, que ampliam um pouco a tonalidade ${ }^{15}$.

Por sua vez, no Carnaval de ilusões de Martinho da Vila observa-se um tratamento muito mais simples, tanto poética quanto musicalmente. Em termos narrativos, o sambista se afasta de um tratamento monumental ao abordar um tema ligado ao universo infantil, ao cotidiano. Musicalmente, como anteriormente exposto, Martinho se mantém naquele loop de acordes estritamente diatônico. Tais características, cabe lembrar, foram repetidas pelo cancionista em outros sambas-enredo que compôs para a Vila Isabel.

Esse pode ser um indício da aproximação que Martinho promoveu entre o samba-enredo e o partido-alto. $\mathrm{Ou}$, na verdade, de uma reaproximação. Isso porque o partido-alto, conforme Nei Lopes, é composto por um refrão, cantado em coro, e uma parte solada, com versos improvisados (LOPES, 1992, p.51) e que o samba composto para o carnaval até o início dos anos 1930 também apresentava uma segunda parte aberta à improvisação de versos (FENERICK, 2005, p.119). Contudo, a partir das intervenções da política varguista no repertório carnavalesco, que objetivavam tirar a imprevisibilidade do samba e fazer com que ele passasse a veicular temas nacionais, o samba-enredo trilhou um caminho independente do partido-alto. É nesse sentido que se pode pensar que Martinho tenha reaproximado esses dois segmentos e, com isso, substituiu o caráter monumental que o samba-enredo havia assumido pela simplicidade do partido-alto.

Em decorrência disso, Martinho foi saudado por alguns críticos musicais e jornalistas do período como um importante renovador do samba-enredo. É o que se percebe, por exemplo, com Tárik de Souza, que afirma que "as modificações que [Martinho] introduziu com a trilogia Carnaval de Ilusões (67), Quatro Séculos de

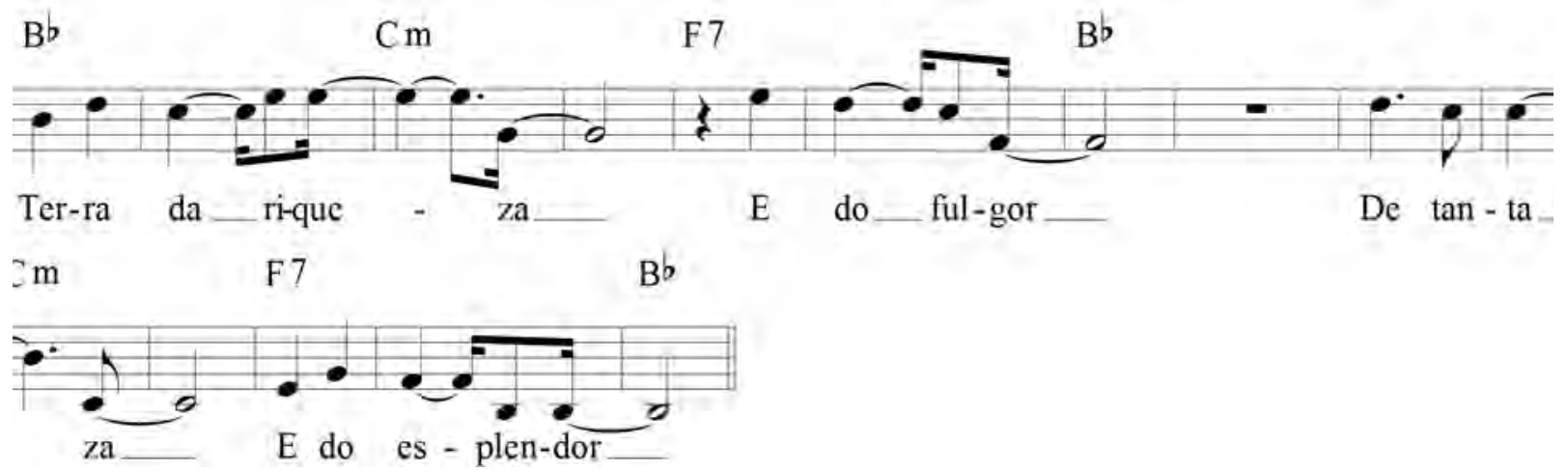

Ex.4 - segunda parte cantada de Carnaval de ilusões (VILA, 1969, lado A, faixa 1, 2min21s a 2min37s) 
Modas (68) e laiá do Cais Dourado (69) foram cruciais" (SOUZA, 1983, p.166) ${ }^{16}$. 0 autor destaca ainda que não eram apenas nas letras que Martinho teria realizado transformações:

0 samba enredo iniciava, desde Martinho, um processo de confluências e modificações que acelerariam seu ritmo, aproximando-o da velocidade da marchinha e dos chamados sambas-de-embalo ou empolgação, que transformariam esse gênero no dominante do carnaval. (SOUZA, 1983, p.166-7)

Contudo, Tárik observa que Martinho não foi renovador somente no samba-enredo, mas que introduziu inovações no próprio partido-alto:

Numa posição paralela com Jorge Ben que fundiu o samba ao cadenciado maracatu, com uma pitada de América Central e rhythm \& blues americano, Martinho apanhou o aleatório partido alto sempre complementado no ato por versos improvisados (o que é obviamente impossivel numa reprodução gravada) e cristalizou-o dando-Ihe estrutura definida e formato identificável, tal como Luiz Gonzaga fez com o difuso baião nordestino. Martinho, portanto, na célebre classificação de Ezra Pound é um inventor, que deu origem a forma conceitualmente nova, que já não guarda senão semelhança com o original. (SOUZA, 1983, p.167-8)

De volta ao fonograma analisado, verificamos que ele apresenta certa unidade entre suas duas partes, uma vez que, antes de apresentar o lado renovador de Martinho presente em Carnaval de ilusões, foi enfatizado o caráter "autêntico" de sua produção musical, mostrando sua ligação com o carnaval e as escolas de samba. Percebe-se, assim, que, para ser visto como alguém capaz de renovar, foi preciso que Martinho se integrasse ao circuito "tradição" para se legitimar. Nesse sentido, ganha destaque o conjunto de ações que acompanhou a trajetória do sambista ao longo da década de 1970 no sentido de aproximá-lo cada vez mais do pólo da "autenticidade" do samba.

\section{5 - Caramba: uma nova e incompreendida "modernização" para o samba}

Após destacar o seu pertencimento à "tradição" do samba com Boa noite e apresentar seu caráter renovador com Carnaval de ilusões, Martinho faz seu terceiro e último comentário no fonograma antes de iniciar a também última canção. Tal comentário ainda se remetia ao samba-enredo Carnaval de ilusões, aludindo à recepção que o mesmo obteve no desfile em que foi apresentado:

Botar música nessa poesia do Gemeu não foi mole, não

E os críticos meteram o pau no samba-enredo

E a Vila perdeu o carnaval

0 meu amigo Chico Buarque de Hollanda dormiu

0 resto da comissão não entendeu nada

No dia do resultado, eu fiz o meu primeiro samba de protesto

(VILA, 1969, lado A, faixa 1, 3min57s a $4 \min 17 \mathrm{~s}$ )

Se o fato de ter anteriormente declamado trechos de Carnaval de ilusões dava destaque à poesia de Gemeu, agora, com o início desse comentário, Martinho chama a atenção de seu ouvinte para sua própria habilidade enquanto compositor ao destacar a dificuldade de transformar aquele texto em um samba-enredo. Por isso, o sambista reclama do pouco reconhecimento que recebeu por parte da comissão julgadora - da qual também participava Chico Buarque - ao realizar essa empreitada. Esse aspecto se encontra desenvolvido no texto de sua canção Caramba, que se segue ao comentário já apresentado. Vejamos sua primeira parte (Ex.5):

Nas duas primeiras frases desse samba ("Fala, fala, falador / Não lhe dou bola porque eu sou bamba"), Martinho diz não estar incomodado diante das más avaliações que recebeu, uma vez que ele é um detentor da "tradição" do samba, visto que se afirma como um bamba. Por sua vez, as frases seguintes ("Malha, malha, malhador / Que não aceita a evolução do samba") completam o discurso do cancionista: como um "autêntico" sambista, ele pode dar um passo da frente no samba, algo que acaba não sendo compreendido ou aceito pelos ouvintes. Isso se encontra reforçado no juízo que Martinho faz sobre a comissão julgadora do desfile, tal como se apresenta na segunda parte de Caramba (Ex.6):

Nesse posicionamento de Martinho, pode-se perceber alguma ressonância daquela figura romântica do gênio: criador, inovador, à frente de seu tempo, e que acaba sendo incompreendido por seus contemporâneos ${ }^{17}$. Em uma matéria de jornal, localizamos uma citação de Martinho na qual o sambista toma para si essa figura de maneira ainda mais clara. Na verdade, o texto dessa matéria trazia críticas ao show do disco Rosa do povo, de Martinho (VILA, 1977, LP). Ainda assim, o jornalista apresentou a fala do próprio sambista, que se defendeu das críticas apoiandose nessa figura do artista incompreendido:

0 espectador paga 60 cruzeiros, senta-se em poltronas desconfortáveis e tem início o show: durante três minutos um gravador reproduz a fita em que Martinho declama o poema Rosa do Povo, de Carlos Drummond de Andrade. Mais tarde, a dose seria repetida: do gravador, no ambiente todo escuro, ouvem-se, por cinco minutos, as vozes de Martinho e João Nogueira cantando um samba da dupla, João e José. Por que não a apresentação do poema e da música ao vivo? Afinal, ninguém ali entrou para ouvir discos. "0 artista é assim mesmo", responde Martinho da Vila, "tem umas ideias diferentes e não pode ficar preocupado se as pessoas vão entender ou não" (SANTOS, 1977, p.92).

Interessante perceber que, se o jornalista em questão não assumia o partido de Martinho, Tárik de Souza, por outro lado, reproduz uma visão muito próxima à do próprio sambista. Após falar sobre as inovações de Martinho no samba-enredo e no partido-alto, o crítico comenta:

Todas essas mudanças mal percebidas ou pouco analisadas dão medida do grau de marginalização cultural a que o samba ainda continua relegado. Apesar de ter sido projetado através da via comum dos festivais, [...] o partido alto de Martinho não pegou carona, sequer como pingente, na chamada linha evolutiva da música popular brasileira. [...] As modificações introduzidas de dentro pelos próprios sambistas com a incorporação de outras influências brasileiras - como são os casos de Paulinho da Viola e Martinho da Vila - permanecem à parte dessa evolução, na verdade paralela e integrada (SOUZA, 1983, p.167, grifo no original)

Como um "autêntico" artista do universo do samba, que consegue inovar em virtude de seu conhecimento 

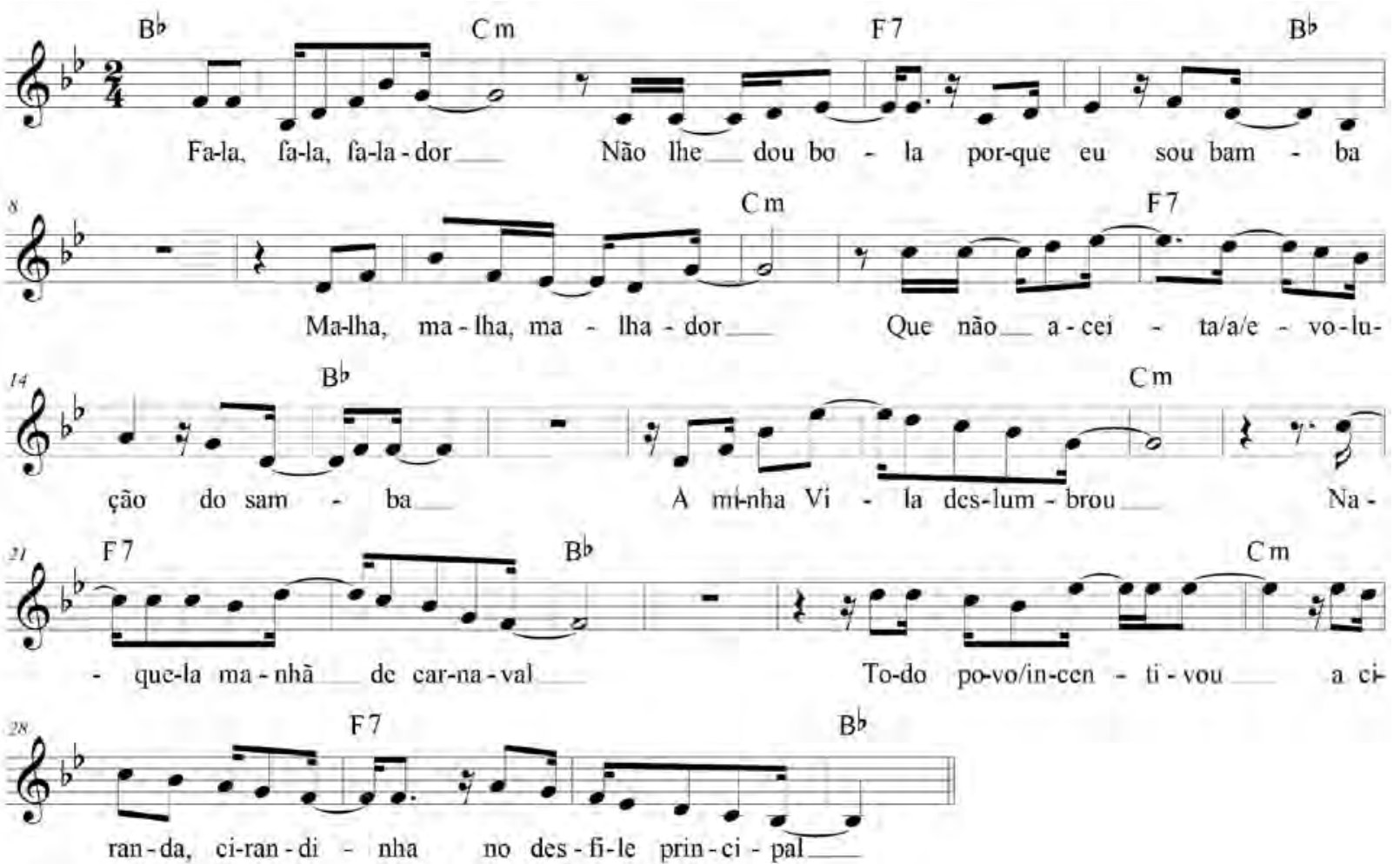

Ex.5 - primeira parte de Caramba (VILA, 1969, lado A, faixa 1, 4min20s a 4min50s)
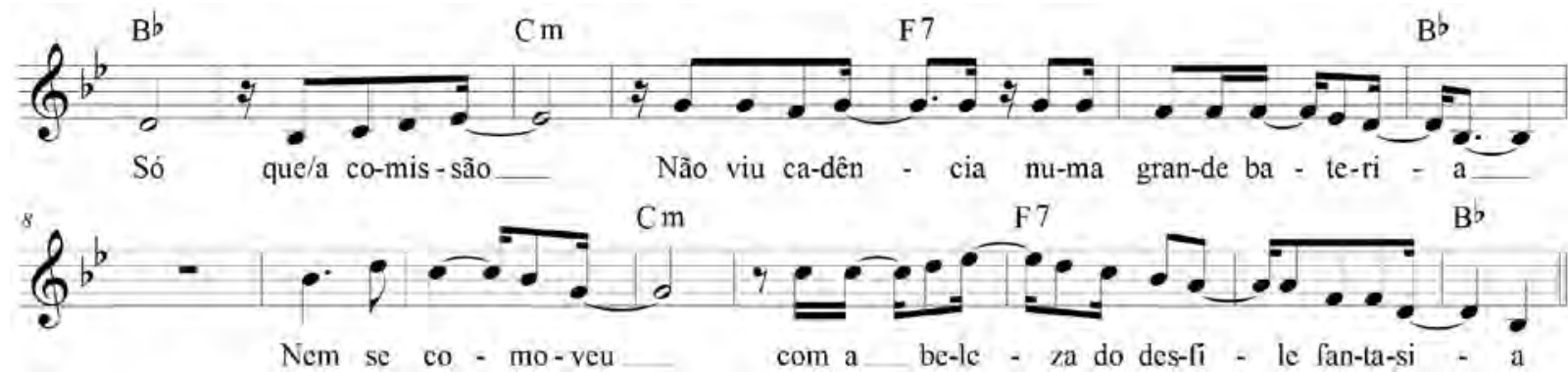

Ex.6 - início da segunda parte de Caramba (VILA, 1969, lado A, faixa 1, 5min8s a 5min24s)

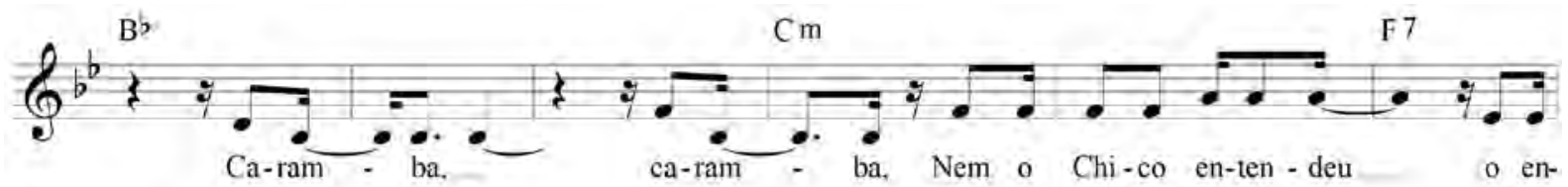

$\mathrm{Bb}$

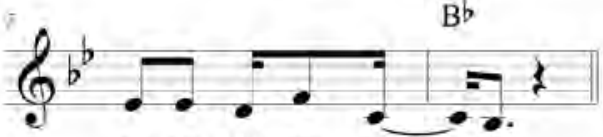

re-do do meu sam - ba

Ex.7 - final de Caramba (VILA, 1969, lado A, faixa 1, 5min24s a 5min32s)

e domínio da "tradição", mas que não é compreendido por seus pares, Martinho finaliza essa canção com um pequeno refrão que retoma a crítica, presente já no comentário que a antecede, a um "monstro sagrado" ${ }^{18} \mathrm{da}$ MPB, Chico Buarque.
Os versos "Nem o Chico entendeu / o enredo do meu samba" trazem uma mensagem bastante forte: nem mesmo um cancionista tão reconhecido como Chico Buarque teria sido capaz de perceber as inovações que Martinho estava fazendo. Nesse sentido, Martinho 
estaria se colocando à frente de Chico, visto que ele representaria a renovação desse repertório, enquanto que este último estaria ainda preso a algum cânone.

Mais do que isso, cabe perceber o novo significado que Martinho atribui ao protesto. É sabido que, para a MPB, a expressão "canção de protesto" era empregada para rotular um repertório engajado, que denunciava injustiças sociais e políticas, convidando para a revolução. Por sua vez, Martinho da Vila, ao caracterizar sua canção "Caramba" como um "samba de protesto", o faz com um novo sentido, uma vez que ele não está reclamando sobre os problemas do "povo", mas está, de certo modo, contestando a legitimidade e a avaliação do júri, inclusive de Chico Buarque. De modo mais amplo, pode-se dizer que o "inimigo" de Martinho nessa canção não é o latifúndio, o imperialismo ou o governo militar, tal qual acontecia na canção de protesto, mas é a própria MPB, que, conforme Napolitano, funcionava como um "totemtabu" da música popular:

Como "totem", sugere cânones, modelos, percepções estéticas e informa valores ideológicos. Como "tabu", delimita, veta e discrimina hierarquias culturais, prescrevendo possibilidades e interdições de escuta (NAPOLITANO, 2005, p.129).

\section{6 - Considerações finais}

Feitos esses apontamentos sobre o primeiro fonograma do LP de estreia de Martinho, espera-se que seja possível visualizar de modo mais claro alguns valores e ideias que estão implícitos nele ${ }^{19}$. Percebemos como essa faixa do disco apontava para seu próprio compositor e intérprete, apresentando-o como um sambista "tradicional" e "autêntico", que conseguia manter a espontaneidade e a simplicidade de sua produção, mesmo atuando no interior da indústria do disco. Além disso, justamente por se apoiar nesse solo firme da "tradição", Martinho ainda se apresentava como um renovador - por vezes, incompreendido - do samba.

Tais características, por sua vez, remetem ao conflituoso cenário da música popular brasileira no período em que Martinho tentava sua inserção. Num contexto em que a MPB definia os cânones e discriminava produções destoantes, 0 sambista foi buscar na "tradição" uma maneira de obter legitimidade nesse campo, e parece ter conseguido certa eficácia nesse processo. Ainda que o sambista não seja reconhecido como um dos grandes cancionistas da música popular do Brasil, sua produção recebeu a admiração de importantes agentes ligados à produção musical e cultural daquela época. Esse foi o caso do já citado jornalista e crítico musical Tárik de Souza, que escreveu matérias elogiosas sobre o repertório de Martinho da Vila (SOUZA, 1978 e 1983). Outro jornalista que apreciava sua produção era Sérgio Cabral, que chegou a dedicar um de seus livros sobre as escolas de samba a "Martinho da Vila e Paulinho da Viola, legítimos herdeiros dos sambistas do Estácio de Sá" (CABRAL, 1974, p.9). Também o poeta Ferreira Gullar não deixou de sinalizar, em 1970, que "Martinho da Vila, com o velho partido alto, repelido pelo festival, continua dando o seu recado" (citado em ZAN, 2010, p.62). Por fim, segundo o depoimento do produtor de Martinho, Rildo Hora, os shows do sambista eram frequentados por artistas e intelectuais da esquerda, dentre os quais destacou o já citado Ferreira Gullar e o dramaturgo Dias Gomes (ver MACHAD0, 2011, p.247).

Assim, o caso de Martinho aponta para a emergência de novos sentidos para o samba naquele período. Até os anos 1960, o samba considerado legítimo era aquele que conscientizava politicamente o "povo" brasileiro, e a "tradição" era valorizada na medida em que favorecia o contato entre o artista-intelectual e o público para quem este deveria se dirigir. Com Martinho, percebe-se que seu processo de legitimação através do vínculo com a "tradição" aconteceu sem que o sambista precisasse fazer a opção pelo engajamento político em suas composições.

Isso não significa que tenha ocorrido uma ruptura radical nos parâmetros de legitimidade na música popular brasileira e tampouco que o engajamento político tivesse deixado de ser um critério de consagração no campo da produção musical do período. Pelo contrário, ao menos até o final da década de 1970, o posicionamento político e a habilidade em driblar a censura e veicular críticas ao regime ditatorial eram vistos como elementos de prestígio para os artistas da MPB, como se percebe no livro do sociólogo Gilberto VASCONCELLOS (1977), que exaltava os cancionistas que se utilizavam dessa "linguagem da fresta". 0 caso de Martinho aponta, na verdade, para o surgimento de uma nova linhagem do samba que, de certo modo, se desvincula da MPB $^{20}$. Se até os anos 1960 o samba era um segmento musical valorizado dentro das perspectivas ideológicas da MPB, há indícios de que, a partir dos anos 1970, uma parte desse segmento encontrava os seus próprios critérios de legitimidade, que consistiam, no caso, em disputas pelo reconhecimento da "autenticidade" das produções.

$E$, nesse aspecto, Martinho da Vila não está sozinho. Na verdade, ele aparece como um primeiro caso (ou um caso de maior destaque) de um grupo maior de sambistas que despontaram no cenário da música popular na década de 1970 e que possuem uma trajetória semelhante à sua. Respeitadas as particularidades estilísticas e biográficas de cada um, podem ser lembrados os nomes de Candeia, Mano Décio da Viola, Aniceto, Silas de Oliveira, Monsueto, Paulinho da Viola, Anescarzinho do Salgueiro, Cartola, Nelson Cavaquinho e Nelson Sargento ${ }^{21}$. Tais sambistas se assemelham pelo fato de terem se projetado na década de 1970 com um tipo de samba que não se pautava pelo engajamento político, mas se assentava na "tradição", sobretudo, por seu vínculo com as escolas de samba.

Essa linhagem provavelmente está nas bases do rótulo "samba de raiz", que foi abordado por TROTTA (2011) em sua pesquisa sobre o "pagode romântico" dos anos 1990. 0 autor salienta que não é possível determinar a partir de quando o termo passou a rotular a produção de sambas, mas se nota que ele foi ganhando força ao 
longo da década de 1990 (TROTTA, 2011, p.209). Segundo o pesquisador, a expressão "samba de raiz"

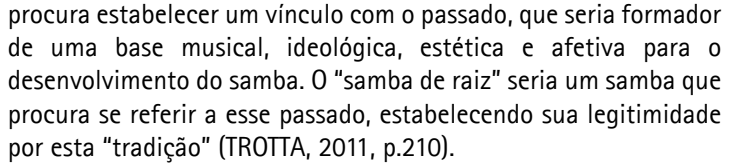
de uma base musical, ideológica, estética e afetiva para 0 desenvolvimento do samba. 0 "samba de raiz" seria um samba que procura se referir a esse passado, estabelecendo sua legitimidade por esta "tradição" (TROTTA, 2011, p.210).

Mesmo no caso do pagode dos anos 1980, parece haver uma orientação em torno da ideia de "tradição". Isso porque toda aquela geração de pagodeiros surgidos no período -Beth Carvalho, Almir Guineto, Zeca Pagodinho, Jorge Aragão, o grupo Fundo de Quintal e outros - se reuniram em torno do bloco carnavalesco do Cacique de Ramos (ver PEREIRA, 2003). Certamente, não se pode desconsiderar o fato de que o Cacique não era propriamente uma escola de samba, e também que o próprio rótulo "pagodeiro" expressa algo até pejorativo, indicando uma espécie de sambista "menor" (TROTTA, 2011, p.213). Contudo, esse mesmo status de bloco carnavalesco, ligado a certa "ancestralidade" do carnaval (lembrando que, historicamente, os blocos antecedem as escolas de samba), associado ao caráter de samba de "fundo de quintal" (uma referência ao local onde o samba era praticado em casarões como os da Tia Ciata), tudo isso conferia certa chancela de "autenticidade" aos seus membros. É justamente a partir do caráter mais "autêntico" dessa produção que a década de 1990 vai criar uma distinção entre o pagode do decênio anterior (que acabou sendo lido como uma espécie de "pagode de raiz") e aquele "pagode romântico" que começava a ser produzido.

Assim, a trajetória de Martinho traz indícios de que ele tenha inaugurado ou, ao menos, protagonizado o início de uma nova linhagem no samba, que se desvinculava da MPB, rompendo com seus parâmetros estéticos e ideológicos, passando a se pautar pelo vínculo com a "tradição" e a "autenticidade". 0 curioso é perceber que tais critérios aparentemente não conflitavam com a inserção no interior da indústria do disco, onde a questão da "autenticidade" fica sensivelmente abalada. Desde as reflexões de Walter Benjamin sobre a obra de arte no contexto da reprodução técnica, sabe-se que "a esfera da autenticidade, como um todo, escapa à reprodutibilidade técnica" (BENJAMIN, 1994, p.167, grifos no original). Isso porque a "autenticidade" de algo está ligada a "tudo o que foi transmitido pela tradição, a partir de sua origem, desde sua duração material até o seu testemunho histórico" (BENJAMIN, 1994, p.168). Esse percurso histórico de uma obra de arte já não pode mais acontecer no contexto da reprodução técnica, quando um objeto (como o filme e o disco) já é criado para ser reproduzido, fazendo com que se perca a ideia da existência de um "original"22. Portanto, na época das técnicas de reprodução, toda a ideia de "autenticidade" ou de "pureza" é resultado de procedimentos técnicos:

\footnotetext{
No estúdio o aparelho impregna tão profundamente o real que o que aparece como realidade "pura", sem o corpo estranho da máquina, é de fato o resultado de um procedimento puramente técnico (...). A realidade, aparentemente depurada de qualquer intervenção humana, acaba se revelando artificial. (BENJAMIN, 1994, p.186, grifos no original).
}

Nesse sentido, aquela busca por estreitar os laços com a "tradição", empreendida por Martinho e outros sambistas dessa linhagem no contexto da indústria fonográfica, aparece também como uma procura por diferencial de mercado. E nisso o sambista de Vila Isabel é exemplar, pois soube desempenhar um papel no qual aparecia como um grande vendedor de discos, sem que isso supostamente abalasse a "pureza" e "autenticidade" de seus sambas.

\section{Referências bibliográficas}

ABRIL CULTURAL. Carlos Lyra. São Paulo, 1971. Contracapa do LP. (Coleção História da Música Popular Brasileira, vol.28) ADORNO, T. W. Theodor W Adorno: sociologia. São Paulo: Ática, 1986.

BENJAMIN, Walter. A obra de arte na era de sua reprodutibilidade técnica. In: BENJAMIN, Walter. Magia e técnica, arte e política: ensaios sobre literatura e história da cultura. 7. ed. São Paulo: Brasiliense, 1994, p.165-196.

BOLÃO, Oscar. Batuque é um privilégio: a percussão na música do Rio de Janeiro para músicos, arranjadores e compositores. São Paulo: Irmãos Vitale, 2010.

CABRAL, Sérgio. As escolas de samba: o quê, quem, como, quando e por quê. Rio de Janeiro: Fontana, 1974. . As escolas de samba do Rio de Janeiro. Rio de Janeiro: Lumiar, 1996.

FREITAS, Sérgio Paulo Ribeiro de. A memória e o valor da síncope: da diferença do que ensinam os antigos e os modernos. Per Musi, Belo Horizonte, n. 22, p.127-149, jul. dez. 2010.

LOPES, Nei. 0 negro no Rio de Janeiro e sua tradição musical: partido-alto, calango, chula e outras cantorias. Rio de Janeiro: Pallas, 1992. Partido-alto: samba de bamba. Rio de Janeiro: Pallas, 2008.

MACHAD0, Adelcio Camilo. Quem te viu, quem te vê: o samba pede passagem para os anos 1970. Dissertação (mestrado) - Universidade Estadual de Campinas, Instituto de Artes, Campinas, 2011.

MEYER, Leonard B. El romanticismo: la ideología de los igualitarios elitistas. El estilo en la música: teoría musical, historia 
e ideología. Madrid: Ediciones Pirámide, 2000, p.253-331.

MOURA, Roberto M. Tia Ciata e a pequena África no Rio de Janeiro. Rio de Janeiro: Instituto Nacional de Música, Divisão de Música Popular, 1983. (Coleção MPB; v. 9).

NAPOLITANO, Marcos. A Música Popular Brasileira (MPB) nos anos 70: resistência política e consumo cultural. In: Actas del IV Congresso Latinoamericano de la Asociación Internacional para el estúdio de la Música Popular, Cidade do México, abril de 2002.

MPB: totem-tabu da vida musical brasileira. Anos 70: trajetórias. São Paulo: lluminuras, 2005, p.125-129. A síncope das ideias: a questão da tradição na música popular brasileira. $1^{\text {a }}$ ed. São Paulo: Fundação Perseu Abramo, 2007.

NAPOLITANO, Marcos e WASSERMAN, Maria Clara. Desde que o samba é samba: a questão das origens no debate historiográfico sobre a música popular brasileira. Revista Brasileira de História, São Paulo, v. 20, n. 39, p.167-189, 2000.

NUNES, Romeo. Martinho da Vila. In: VILA, Martinho da. Meu laiaraiá. RCA Victor, 1970. LP.

PEREIRA, Carlos Alberto Messeder. Cacique de Ramos: uma história que deu samba. Rio de Janeiro: E-Papers, 2003.

RIDENTI, Marcelo. Em busca do povo brasileiro. Rio de Janeiro: Record, 2000.

Brasilidade revolucionária: um século de cultura e política. São Paulo: Editora UNESP, 2010.

SANDRONI, Carlos. Feitiço decente: transformações do samba no Rio de Janeiro, 1917-1933. Rio de Janeiro: Jorge Zahar Ed./Ed. UFRJ, 2001.

SANTOS, Fábio Saito dos. Estamos aí: um estudo sobre as influências do Jazz na Bossa-Nova. Dissertação (mestrado) Universidade Estadual de Campinas, Instituto de Artes, Campinas, 2006.

SANTOS, Joaquim Ferreira dos. Ingênua vanguarda. Veja, nº 436, 12-01-1977, p.92.

SARAIVA, Joana Martins. A invenção do sambajazz: discursos sobre a cena musical de Copacabana no final dos anos de 1950 e início dos anos 1960. Dissertação (mestrado) - Pontifícia Universidade Católica do Rio de Janeiro, Rio de Janeiro, 2007.

SOUZA, Tárik de. Nada de paetês. Veja, n 535, 6-12-1978, p.109-110.

Martinho da Vila: o bamba que não bambeia. O som nosso de cada dia. Porto Alegre: L\&PM, 1983, p. 166-168.

SOUZA, Tárik de; ANDREATO, Elifas. Rostos e gostos da música popular brasileira. Porto Alegre: L\&PM, 1979.

TAGG, Philip. Everyday tonality: towards a tonal theory of what most people hear. New York \&t Montreal: The Mass Media Music Scholars' Press, 2009.

TR0TTA, Felipe. O samba e suas fronteiras: "pagode romântico" e "samba de raiz" nos anos 1990. Rio de Janeiro: Editora UFRJ, 2011. (Col. História, Cultura e Ideias, v.12)

VASCONCELLOS, Gilberto. Música popular: de olho na fresta. Rio de Janeiro: Edições do Graal, 1977.

TATIT, Luiz. O século da canção. São Paulo: Ateliê Editorial, 2004.

VIANNA, Hermano. O mistério do samba. Rio de Janeiro: Jorge Zahar Editor/editora UFRJ, 1995.

VIZEU, Carla. 0 samba-enredo carioca e suas transformações nas décadas de 70 e 80: uma análise musical. Dissertação (mestrado) - Universidade Estadual de Campinas, Instituto de Artes, Campinas, 2004.

ZAN, José Roberto. Jards Macalé: desafinando coros em tempos sombrios. Revista USP, n.87, set/out/nov-2010, p.156-171.

\section{Referências fonográficas e audiovisuais}

ALF, Johnny. Rapaz de bem / 0 tempo e o vento. Continental, 1955. 78 rotações.

ALMIRANTE. Almirante. Fontana, 1968. LP.

GOULART, Jorge. A voz do morro / A mão que afaga. Continental, 1955. 78 rotações.

HISTÓRIA das Escolas de Samba, vol.1. Som Livre, 1975. LP.

LYRA, Carlos. Depois do carnaval. Philips, 1963. LP.

RICARDO, Sérgio. A bossa romântica de Sérgio Ricardo. Odeon, 1960. LP.

VILA, Martinho da. Martinho da Vila. RCA Victor, 1969. LP.

Meu laiaraiá. RCA Victor, 1970. LP.

Memórias de um sargento de milícias. RCA Victor, 1971. LP.

Batuque na cozinha. RCA Victor, 1972. LP.

Origens (Pelo telefone). RCA Victor, 1973. LP.

Canta canta minha gente. RCA Victor, 1974. LP.

Rosa do povo. RCA Victor, 1977. LP.

Tendinha. RCA Victor, 1978. LP. 


\section{Notas}

1 Agradeço a leitura atenta e as preciosas sugestões de meu orientador, Prof. Dr. José Roberto Zan.

2 A questão da "origem" do samba consiste em um amplo debate travado ao longo da história da música popular brasileira. 0 samba é carioca ou baiano? "Nasceu" nos morros ou nas casas das tias baianas? Tais são alguns dos questionamentos em que esse debate se pauta. Para um melhor mapeamento e discussão desse assunto, ver NAPOLITANO e WASSERMAN, 2000.

3 Sobre essa canção, vale conferir a análise de SANTOS (2006, p.44-53), que atenta para os elementos jazzísticos nela presentes.

4 Durante minha pesquisa de mestrado, tive acesso às listagens do IBOPE, disponiveis no Arquivo Edgar Leuenroth, na UNICAMP. Ao final da dissertação, encontra-se uma tabela ilustrando as aparições de Martinho da Vila nessas listas (ver MACHADO, 2011, p.278-281).

5 A baiana Hilária Batista de Almeida, a Tia Ciata, era uma das lideranças espirituais da comunidade negra do Rio de Janeiro. Casada com o funcionário público João Batista, sua casa oferecia a proteção necessária para que se realizassem práticas culturais e religiosas dos negros, duramente reprimidas naquele início do século XX (cf. MOURA, 1983, p.64-66).

6 SANDRONI (p.118) nos lembra que, antes de Pelo telefone, outras canções com a indicação de samba já haviam sido gravadas. Contudo, elas acabaram passando despercebidas, o que não aconteceu com a canção de Donga e Mauro de Almeida, que obteve grande sucesso no carnaval de 1917 e se tornou um "marco" na historiografia do samba.

7 Em seu show 0 pequeno burguês, gravado em DVD em 2008, Martinho dá um depoimento no qual afirma ter colocado a "cadência" do partidoalto no samba-enredo. Para demonstrá-lo, Martinho executa no pandeiro um padrão rítmico que pode ser entendido como uma variação daquele apresentado por Bolão:

8 Vide, por exemplo, a letra de seu partido-alto Quem é do mar não enjoa: "Quem é do mar não enjoa / Não enjoa / Chuva fininha é garoa / É garoa / Homem que é homem não chora / Não, não chora / Quando a mulher vai embora / Vai embora" (VILA, 1969, lado B, faixa 01).

9 A essa caracteristica harmônica, Philip TAGG (2009, p.199 e seguintes) chamou de loops de acordes.

10 Interessante comparar as definições de partido-alto apresentadas em duas publicações de Nei Lopes. Na introdução de seu livro mais recente (LOPES, 2008, p.26-7), o autor repete, palavra por palavra, a definição de partido-alto que havia apresentado anteriormente (LOPES, 1992, p.51). Contudo, no livro de 2008, o autor conclui a definição com um parágrafo que destaca o humore a espontaneidade do partido-alto, e ainda o coloca como vinculado à elite dos sambistas: "Transcendendo qualquer aspecto formal, partido-alto é, sobretudo, o samba da elite dos sambistas, bemhumorado, encantador e espontâneo" (LOPES, 2008, p.27).

11 Em sua investigação sobre o repertório do calango, Lopes destaca a existência de desafios "na linha do á, do é, do $i$, do ó, do $u$, do ão, e por ai afora" (LOPES, 1992, p.30). Interessante destacar isso, pois nos faz recordar do próprio samba Linha do Ão, de Martinho da Vila.

12 A questão da dissonância foi cuidadosamente tratada em um artigo de Freitas, que mostrou como a competência para lidar com ela foi sendo historicamente constituída como um sinal de "habilidade, beleza, esmero, maestria, [...] agudeza e engenho" (FREITAS, 2010, p.138).

13 Nesse sentido, Napolitano lembra a atuação de Almirante como radialista, sobretudo a partir de seu programa No tempo de Noel Rosa, de 1951, no sentido de consolidar a memória de Noel como um dos "grandes mestres" do samba: "Suas palestras sobre Noel consagravam os elementos criativos e biográficos que apontavam para a heroicização do poeta da Vila, digno inventor do samba moderno, ao lado de Ismael Silva, Pixinguinha, Cartola e outros" (NAPOLITANO, 2007, p.62).

14 A pesquisadora Carla Vizeu nos mostra que, na segunda metade dos anos 1930, houve um decreto que obrigava as escolas de samba a empregarem temas nacionais em seus enredos (VIZEU, 2004, p.47-50). Nos anos 1950, isso acabou se consolidando nos chamados sambas-lençol, que discorrem "sobre um tema histórico com riqueza de detalhes", prática que teve em Silas de Oliveira um de seus expoentes (VIZEU, 2004, p.50).

15 Tais observações se baseiam na gravação desse samba-enredo presente no primeiro volume da coletânea de LPs História das Escolas de Samba (HISTÓRIA, 1975, LP).

16 Cabe lembrar que esses outros dois sambas-enredo, Quatro séculos de modas e costumes e laiá do Cais Dourado, também foram gravados no LP de estreia de Martinho.

17 Uma abordagem sobre a figura do gênio romântico na música pode ser encontrada em MEYER (2000). 0 autor entende que é provável que toda a cultura ocidental tenha sido marcada por uma tensão entre o classicismo apolíneo (valorização das convenções, coerência das formas) e o romantismo dionisiaco (valorização das particularidades e da inovação individual). Mas Meyer entende que o último romantismo, que se iniciou no final do século XVIII, consistiu numa transformação profunda na perspectiva social, politica e ideológica (e, poderiamos acrescentar, estética) cujos efeitos ainda são perceptiveis contemporaneamente.

18 A expressão é de NAPOLITANO (2002).

19 Mesmo que o pensamento de Theodor Adorno seja especialmente crítico em relação à produção em música popular, o que se busca nesse trabalho é, conforme proposto por este autor, estar atento ao modo "como momentos da estrutura social, posições, ideologias e seja lá o que for conseguem se impor nas próprias obras de arte" (ADORNO, 1986, p.114).

20 Acredito que não seria correto dizer que tenha ocorrido uma separação entre o samba e a MPB. Ao contrário, um caso como o de João Bosco mostra que o samba continuava a fazer parte do repertório desse segmento hegemônico da música popular brasileira. É nesse sentido que parece preferivel pensar em uma nova linhagem do samba, que não substitui a anterior, mas se apresenta como uma nova possibilidade.

21 Caberia lembrar que Silas de Oliveira e Monsueto faleceram respectivamente em 1972 e 1973, mas que tiveram regravações de sambas de sua autoria durante a década de 1970, inclusive pelo próprio Martinho. Também há sambistas que haviam aparecido já no contexto da canção engajada, mas que não assumem essa postura, buscando se pautar pelo vínculo com a "tradição" e as escolas de samba, como são os casos de Paulinho da Viola (da Portela), de Anescarzinho do Salgueiro, e de Cartola, Nelson Cavaquinho e Nelson Sargento (da Mangueira).

22 BENJAMIN (1994, p.167-8) esclarece que, no contexto anterior à reprodutibilidade técnica, o objeto original "conserva toda a sua autoridade com relação à reprodução manual, em geral considerada uma falsificação". É essa autoridade de um objeto original que desaparece com a reprodução técnica, pois já não se pode identificar qual é o original de um jornal, de um filme, de uma fotografia ou de um disco.

Adelcio Camilo Machado é aluno do Doutorado em Música pela Universidade Estadual de Campinas (UNICAMP), onde desenvolve pesquisa sobre a música popular brasileira das décadas de 1940 e 1950 sob a orientação do Prof. Dr. José Roberto Zan e com financiamento da FAPESP. Desde 2009 é integrante do Grupo de Pesquisa Música popular: história, produção e linguagem, que é coordenado por seu orientador e pelo Prof. Dr. Antonio Rafael Carvalho dos Santos. 